\title{
Effects of starvation and stocking density on the physiology of the male of the southern king crab Lithodes santolla
}

\author{
Hernán Javier Sacristán ${ }^{\mathrm{a}, *}$, Pablo Di Salvatore ${ }^{\mathrm{a}}$, Analía Verónica Fernández-Gimenez ${ }^{\mathrm{b}}$, \\ Gustavo Alejandro Lovrich ${ }^{\mathrm{a}}$ \\ ${ }^{a}$ Centro Austral de Investigaciones Científicas, CADIC- CONICET, Houssay 200, Ushuaia, V9410CAB, Argentina \\ ${ }^{\mathrm{b}}$ Instituto de Investigaciones Marinas y Costeras, Universidad Nacional de Mar del Plata, CONICET, Facultad de Ciencias Exactas y Naturales, Funes 3350, Mar del Plata, \\ B7602AYL, Argentina
}

\section{A R T I C L E I N F O}

Handled by A.E. Punt

Keywords:

Beagle channel

Chile

King crab

Energetic reserves

Oxidative stress

Decapods

\begin{abstract}
A B S T R A C T
The southern king crab (SKC) Lithodes santolla is an important commercial species in southern South America. There is a greater need for availability of fresh and live crabs during the season of highest demand in summer (mainly December and January). Thus, this study aimed to determine the effects of starvation and stocking densities on the physiological status of male SKC to know whether SKC can be stocked after they are fished. To assess the effects of starvation, crabs were assigned to two experimental groups: the Laboratory group (in which crabs were either fed daily (controls), fed every 15 days, or starved and the Sea group (in which crabs were either fed every 15 days or starved). Starved crabs showed a very slight mass reduction $(<5 \%)$, glycogen depletion from the midgut gland (when kept at sea), lipid peroxidation reduction in both the muscle and the midgut gland, and micro-structural alterations of the midgut gland. Starved crabs were then analyzed at three stocking density levels: low ( $35 \mathrm{crabs}^{-3}$ ), medium $\left(69 \mathrm{crabs}^{-3}\right)$, and high $\left(115 \mathrm{crabs}^{-3}\right)$ for 30 days. In this experiment, we found, at all densities, a decreased weight of the midgut gland, a low condition index, decreased lipase activity, glycogen reduction, increased protein reserves, and lipid peroxidation reduction, and decreased lipid levels at low and medium densities. The muscle showed, at all densities, an increased protein oxidation and a decrease in the RNA:DNA ratio. Our results suggest that SKC can tolerate relatively high stocking densities, have low mortality, and are able to endure 60 days of food deprivation without lowering their flesh yield. This would allow marketing crabs alive off-season.
\end{abstract}

\section{Introduction}

The southern king crab (SKC) Lithodes santolla is an important commercial species that has been fished in southern South America since the 1970s. In the last five years, landings have averaged ca. $9900 \mathrm{t}$ per year, with most captures from Chilean waters mainly south of $50^{\circ} \mathrm{S}$, and from the Atlantic waters near the city of Comodoro Rivadavia, Argentina, ca. $45^{\circ} \mathrm{S} 60^{\circ} \mathrm{W}$ (Lovrich and Tapella, 2014; FAO, 2017). The Argentine fishery for L. santolla in the Beagle Channel is smaller, with landings of ca. $50 \mathrm{t}$ per year during the last five years. In 1994, the authorities decided to close the SKC fishery in the sector of the Beagle Channel near Ushuaia to preserve the commercial stock because this area had received the highest fishing pressure since the start of the SKC fishery in the 1930s (catch-per-unit-effort values as low as two individuals per trap, along with only $11 \%$ of ovigerous females; Lovrich and Tapella, 2014). The fishery remained closed until 2013.

Current regulations for South American king crab fisheries are based on the selection of the sex and size of the crabs fished (only males of $110 \mathrm{~mm}$ carapace length (CL) in Argentina and of $120 \mathrm{~mm}$ CL in Chile; Lovrich et al., 2002), and on a limited fishing season. The closed season was only in November and December until 2013. This had the objective to preserve the reproductive potential of the population by allowing males to mate at least once before attaining legal size, and by avoiding interference in the formation of mating couples. Since 2013, the closed season has been between March and June, which allows protection of the male molting period (mainly in May).

Ushuaia, which is an important tourist destination, the SKC is highly sold mainly alive, with specimens exhibited in restaurant showcases, which hat maximizes the commercial value of this crab. Ushuaia is one of the few destinations where SKC are sold as fresh fish of the day.

\footnotetext{
* Corresponding author at: Centro Austral de Investigaciones Científicas (CADIC-CONICET), Houssay 200, V9410CAB Ushuaia, Tierra del Fuego, Argentina.

E-mail addresses: hernansacristan@cadic-conicet.gob.ar (H.J. Sacristán), pablodisalva@gmail.com (P. Di Salvatore), fgimenez@mdp.edu.ar (A.V. Fernández-Gimenez), lovrich@cadic-conicet.gob.ar (G.A. Lovrich).
} 
Southern King crabs have therefore become a high-quality product and a local gastronomic attraction with high demand, especially during the high tourist season, in summer (December to March). The fishing season in the Beagle Channel was closed at the time this study was conceived. In addition, fresh crabs were rarely available until February as a result of the constant bad weather in January, which interrupted artisan fishing trips. This situation and the need for availability of fresh and live crabs particularly during the season of highest demand in summer (mainly December and January) led us to wonder whether SKC can be stocked (held) and/or starved for long periods after they are fished.

Research on starving, holding, maintenance and stocking density in crabs from cold waters is limited. For example, under starvation conditions, snow crab Chionoecetes opilio decreases its muscular mass, midgut gland weight, muscular enzymatic activity and DNA level, and increases its water content (Mayrand et al., 2000). In the red king crab Paralithodes camtschaticus, mortality increases with increasing stocking densities, the percentage of meat content decreases after 56 days of starvation, and starved individuals kept at a stocking density of $60 \mathrm{~kg}$ $\mathrm{m}^{-3}$ have reduced meat content but no mortality (Siikavuopio et al., 2016). The risk of mortality increases in C. opilio males stored at densities higher than $25 \mathrm{~kg} \mathrm{~m}^{-3}$ for 3 weeks (Siikavuopio et al., 2017). The effect of long-term holding on L. santolla metabolism to market them off-season has not been studied to date.

The meat content of crabs can be affected by the season, harvest location and their physiological condition, and can be improved by feeding them during the holding period (Hjelset and Sundet, 2004; Siikavuopio et al., 2011, 2016; James et al., 2013; Stevens, 2014; Siikavuopio and James, 2015; Lorentzen et al., 2019). Meat content is related to yield, which can be defined as the final weight of the raw or cooked appendages relative to the weight of the whole raw crab (Lorentzen et al., 2019). The midgut gland or hepatopancreas of crustaceans plays a key role during growth and molting because it is the principal organ for synthesis and secretion of digestive enzymes, and absorption and storage of nutrients, such as lipids and glycogen, which can be mobilized during non-feeding periods (Icely and Nott, 1992; Ong and Johnston, 2006). Histologically, the functional unit of the midgut gland is a blind tubule with a simple cylindrical epithelium (Sousa and Petriella, 2006), consisting of different cell types, namely: E-cells (embryonic), R-cells (resorptive), F-cells (fibrillar) and B-cells (blisterlike) (Gibson and Barker, 1979; Al-Mohanna and Nott, 1987; Caceci et al., 1988; Icely and Nott, 1992; Franceschini-Vicentini et al., 2009). The midgut gland structure can be modified by several factors such as food deprivation, changes in salinity, and food ingredients (Jones and Obst, 2000; Li et al., 2008; Anger and Hayd, 2009; Díaz et al., 2010; Calvo et al., 2011; Sacristán et al., 2015, 2016). However, histological changes in this organ have never been examined in L. santolla.

Thus, the aim of this study was to determine the effects of starvation and stocking densities on the physiological state of male SKC to determine whether long-term holding of these crabs under starvation may allow them to be retailed off-season. To this end, we performed a histological analysis of the midgut gland of male Lithodes santolla captured in the Beagle Channel, Tierra del Fuego, Argentina, and analyzed changes in mass, energetic reserves (glycogen, lipid and protein), nucleic acids, lipid peroxidation, protein oxidation, and digestive enzymes (protease and lipase) in both the midgut gland and pereopod muscle.

\section{Materials and methods}

\subsection{Sampling}

Male L. santolla were captured in the Beagle Channel using baited commercial traps. The crabs were transported to the aquarium facilities of the Centro Austral de Investigaciones Científicas (CADIC), Ushuaia, and kept in two fiberglass tanks $(2.67 \mathrm{~m}$ long $\mathrm{x} 1.70 \mathrm{~m}$ wide $\mathrm{x} 0.60 \mathrm{~m}$ high) with a chilled seawater recirculation system at $6-8{ }^{\circ} \mathrm{C}$ and a photoperiod cycle of $10 \mathrm{~h}$ light:14 h dark. Fiberglass tanks were filled with natural seawater brought from the Beagle Chanel coast, which was stocked in 3000-L tanks before circulating through a closed system. Water quality was maintained using mechanical $(50 \mu \mathrm{m})$ and biological filters, and a UV-sterilizer, and by replacing part of the water to maintain water quality (see below). Crabs were fed daily ad libitum with fresh squid mantle. Under this condition, the animals were acclimated to the aquarium environment for 1 week.

\subsection{Experimental design}

2.2.1. Experiment 1: Effects of feeding crabs every 15 days and starvation Ninety crabs in intermolt stage (averaging $1.23 \pm 0.45 \mathrm{~kg}$ body mass; $115.10 \pm 13.26 \mathrm{~mm} \mathrm{CL}$ ) were randomly divided into two experimental groups: the Laboratory group $(\mathrm{N}=54)$ and the Sea group $(\mathrm{N}=36)$. The animals of the Laboratory group $(\mathrm{L})$ were randomly and equally distributed in three treatments: 1) daily fed ad libitum with fresh squid mantle during the 60 days of the experimental period (August-September 2015) (L-F), which served as the control group, 2) fed every 15 days (L-15 F), and 3) starvation, i.e. not fed until day 60 (L$\mathrm{S})$. The crabs kept at sea (S) were randomly and equally distributed in two treatments: 1) fed every 15 days (S-15 F) and 2) starvation (S-S).

The crabs of the Laboratory group were placed in individual plastic containers $(65 \mathrm{~cm}$ long $\mathrm{x} 45 \mathrm{~cm}$ wide $\mathrm{x} 30 \mathrm{~cm}$ high) filled with natural seawater and connected to a chilled seawater recirculation system at $6-8{ }^{\circ} \mathrm{C}$ and a photoperiod cycle of $10 \mathrm{~h}$ light: $14 \mathrm{~h}$ dark. Water quality was kept similar to that of the Beagle Channel: $\mathrm{pH}$ at $6.92-7.63$, salinity at $32.45-32.77$, total dissolved solids at $20.45-25.31 \mathrm{ppt}$, nitrites at $0.3-1.6 \mathrm{mg} \mathrm{L}^{-1}$, nitrates at $50-100 \mathrm{mg} \mathrm{L}^{-1}$ and no ammonium $\left(0 \mathrm{mg} \mathrm{L}^{-1}\right)$.

The crabs of the Sea group were kept in individual perforated plastic containers ( $65 \mathrm{~cm}$ width $\mathrm{x} 45 \mathrm{~cm}$ length $\mathrm{x} 30 \mathrm{~cm}$ height) and anchored to a long-line $5 \mathrm{~m}$ above the sea bottom, close to Punta Oriental ( $54^{\circ} 50^{\prime} \mathrm{S}$ $68^{\circ} 15^{\prime} \mathrm{W}$ ), in the Beagle Channel, near Ushuaia.

Crabs were sampled at 30, 45 and 60 days. At each sampling, six crabs exposed to each treatment in the two groups were extracted from the aquarium and the plastic containers, drained with the rostrum facing the floor for $20 \mathrm{~s}$, and their size measured as carapace length. They were subsequently placed in a bucket, and weighed with a portable digital scale (WeiHeng. Precision: $0.001 \mathrm{~kg}$ ), and dissected. Midgut glands and a small portion of the pereopod muscle (third right walking leg) were separated and frozen at $-80^{\circ} \mathrm{C}$.

The "wild" condition of physiological parameters was studied in six additional crabs, by analyzing the same parameters (see sections below) immediately after their capture from the wild.

\subsubsection{Experiment 2: Effect of stocking density during starvation}

Fifty-four crabs in intermolt stage (averaging $1.09 \pm 0.39 \mathrm{~kg}$ body mass; $106.58 \pm 10.64 \mathrm{~mm} \mathrm{CL}$ ) were randomly and assigned into three treatments: low density (LD; $\mathrm{N}=18 ; 35$ crabs $\mathrm{m}^{-3}$ ), medium density

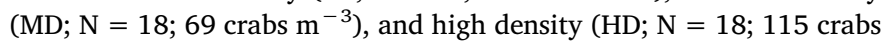
$\mathrm{m}^{-3}$ ). Within each treatment, crabs were randomly assigned to six plastic containers in which only the width was variable $(50 \mathrm{~cm}$ long $\times 35 \mathrm{~cm}$ high, and $48 \mathrm{~cm}, 25 \mathrm{~cm}$ or $15 \mathrm{~cm}$ wide for the LD, MD and HD treatments respectively). Each plastic aquarium contained three crabs that were maintained without food for 30 days during October 2016. All containers were connected to a chilled seawater recirculation system at conditions similar to those described above. Each container was considered a replicate (six replicates/treatment). Water quality, temperature and photoperiod were similar to those mentioned before.

At the end of experiment 2 (30 days), crabs were sampled, weighed and their carapace length measured in conditions similar to those described in experiment 1. Each midgut gland and muscle was dissected and frozen at $-80^{\circ} \mathrm{C}$. The "wild" condition of physiological parameters was studied in six additional crabs, by analyzing the same parameters (see sections below) immediately after capture. 


\subsection{Physiological condition}

The change in wet weight was calculated as the percent weight variation of the difference between the final and initial wet weights. The midgut gland index (MGI) and muscle water content were estimated in experiments 1 and 2, while histological analysis was carried out only for experiment 1 . The MGI was calculated to assess the potential mobilization of metabolic reserves during the experiments. This index was calculated as MGI (\%) = (midgut gland mass/whole body mass) $\times 100$. The meat yield (MY\%) was calculated as the percent ratio between the final mass of appendages and the whole body mass. The muscle water content was determined from the third left walking pereopod, which was individually wet-weighed and dried at $60^{\circ} \mathrm{C}$ to constant weight. The percent muscle water content was calculated as (Initial weight-Final weight)/Initial weight $\times 100$.

Histological analyses of the midgut gland at 30, 45 and 60 days were performed in three crabs per time. A small portion of each midgut gland was fixed in Bouin's solution and processed using a routine histological method. Briefly, the midgut gland tissues were dehydrated in an alcohol series, embedded in paraffin, and 6- $\mu \mathrm{m}$ sections were stained with hematoxylin-eosin and analyzed under light microscopy. Abnormalities in the midgut gland structure were described based on previous studies in other decapod crustaceans (Calvo et al., 2012, 2013; Sacristán et al., 2016).

Small portions, in the order of milligrams, of each midgut gland and pereopod muscle were used to measure the contents of glycogen, lipids, and nucleic acids (only in muscle). The rest of the organ was used to assess the soluble protein content, lipid peroxidation and protein oxidation levels, as well as lipase and protease activities. All determinations were run in triplicate.

\subsubsection{Activity of digestive enzymes in the midgut gland}

Each midgut gland (100-150 mg) was homogenized in cold Tris- $\mathrm{HCl}$ (120 mM, pH 7.5, 1:4 w/v) using a potter homogenizer (Vijayavel et al., 2004). After centrifugation (Sigma $3-18 \mathrm{~K}$ ) at $10,000 \times \mathrm{g}$ for $30 \mathrm{~min}$ at $4{ }^{\circ} \mathrm{C}$, the lipid layer fraction was removed and the supernatant (enzyme extract) was stored at $-80^{\circ} \mathrm{C}$ until used as enzyme extract.

Total protease activity was assayed using $1 \%$ azocasein as the substrate in $50 \mathrm{mM}$ Tris HCl, pH 7.5 (García-Carreño, 1992). One protease unit was defined as the amount of enzyme required to increase the optical density by 0.01 OD units at $440 \mathrm{~nm}$ (Lopez-Lopez et al., 2005).

The lipase activity of each enzyme extract was determined according to Versaw et al. (1989). The assay mixture consisted of sodium taurocholate $100 \mathrm{mM}$, buffer TRIS $\mathrm{HCl} 50 \mathrm{mM}, \mathrm{pH} 7.5$ and the enzyme extract. After incubation $\left(25^{\circ} \mathrm{C}\right.$ for $\left.5 \mathrm{~min}\right)$, the substrate $\beta$-naphthylcaprylate (Goldbio N-100) dissolved in dimethyl sulfoxide (DMSO) was added to the mixture, and the mixture incubated at $25^{\circ} \mathrm{C}$ for an additional $30 \mathrm{~min}$ before adding $20 \mu \mathrm{L}$ Fast Blue BB (100 mM in DMSO). The reaction was stopped with trichloroacetic acid $(0.72 \mathrm{~N})$ and clarified with ethyl acetate:ethanol $(1: 1 \mathrm{v} / \mathrm{v})$. Absorbance was recorded at $550 \mathrm{~nm}$. One lipase unit was defined as the amount of enzyme required to cause an increase of 0.01 OD units at $550 \mathrm{~nm}$ (Lopez-Lopez et al., 2005).

\subsubsection{Energetic reserves of the midgut gland and muscle}

Total lipids were extracted following Folch's protocol (Folch et al., 1957). Lipids were extracted by homogenizing pre-weighed samples of the midgut gland or muscle with a mixture of chloroform:methanol (2:1 $\mathrm{v} / \mathrm{v}$ ). The homogenate was filtered through a funnel with a filter paper to recover the liquid phase. Subsequently, liquid samples were washed with a $\mathrm{NaCl}$ solution $(0.9 \%)$ to obtain two layers. Total lipids were determined by the sulfophospho-vanillin method (Frings and Dunn, 1970). This method consists of oxidizing cellular lipids to small fragments after a chemical digestion with hot concentrated sulfuric acid. After the addition of a solution of vanillin and phosphoric acid, a fuchsia complex was formed and its absorbance was read at $530 \mathrm{~nm}$ on a CINTRA 10e CBC spectrophotometer. The standard solution was prepared with commercial extra virgin olive oil (Cocinero, Molinos Río de la Plata S.A., Argentina). Lipids were expressed as milligrams of lipids per gram of tissue.

Glycogen concentration was measured based on Lo et al. (1970). In a glass tube, $1 \mathrm{~mL}$ of $30 \% \mathrm{KOH}$ saturated with $\mathrm{Na}_{2} \mathrm{SO}_{4}$ was added to the pre-weighed sample. Tubes with their screw cap were placed in a boiling water bath for $1 \mathrm{~h}$, and then cooled on ice. Then, $1 \mathrm{~mL}$ of ethanol $96^{\circ}$ was added to precipitate the glycogen. The samples were placed on ice for $30 \mathrm{~min}$ and then centrifuged (ROLCO 2036) at $4500 \mathrm{rpm}$ for $10 \mathrm{~min}$. The glycogen precipitates were next dissolved in $1 \mathrm{~mL}$ of distilled water. An aliquot of $300 \mu \mathrm{L}$ of the above glycogen solution was brought to a sample volume of $1 \mathrm{~mL}$ by the addition of distilled water, $1 \mathrm{~mL}$ of $8 \%$ phenol solution, and $5 \mathrm{~mL}$ of $\mathrm{H}_{2} \mathrm{SO}_{4}$. Subsequently, the tubes were allowed to stand for $10 \mathrm{~min}$, shaken and placed for $10-20 \mathrm{~min}$ in a water bath at $25-30^{\circ} \mathrm{C}$, and readings were taken. The absorption spectrum was read at $490 \mathrm{~nm}$ and the standard solution was prepared with rabbit glycogen (Sigma G0885). Glycogen was expressed as milligram of glycogen per gram of tissue. Finally, total soluble protein was evaluated with the Coomassie blue dye method by using serum bovine albumin as the standard (Sigma A6003) (Bradford, 1976). Soluble protein was expressed as milligram of protein per milliliter of supernatant.

\subsubsection{Oxidative damage in the midgut gland and muscle}

The lipid peroxidation level was measured according to the protocol of Buege and Aust (1978) by the formation of thiobarbituric acid reactive substances (TBARS). Enzyme extract was added to the reaction mixture (trichloroacetic acid 15\% (w/v), 2-thiobarbituric acid $0.375 \%$ $(\mathrm{w} / \mathrm{v})$, and butylhydroxytoluene $0.147 \mathrm{mM})$ in a ratio of $1: 5(\mathrm{v} / \mathrm{v})$. The mixture was vigorously shaken, maintained in boiling water for $60 \mathrm{~min}$, and immediately cooled at $5{ }^{\circ} \mathrm{C}$ for 5 min (Ohkawa et al., 1979). Then, it was centrifuged at $5000 \times \mathrm{g}$ for $10 \mathrm{~min}$, and the supernatant was measured spectrophotometrically at $535 \mathrm{~nm}$.

The protein oxidation level was evaluated based on Reznick and Packer (1994) by detecting the formation of protein hydrazones as a result of the reaction of dinitrophenyl hydrazine with protein carbonyls. Some minor modifications to the original protocol were performed (Ansaldo et al., 2007). Briefly, after the formation of protein hydrazones, these were precipitated using trichloroacetic acid 30\% (Fagan et al., 1999), and washed three times with ethanol:ethyl acetate (1:1 v/ v). After the final wash, the proteins were solubilized in $1 \mathrm{~mL}$ of urea (6 $\mathrm{M}$ in $20 \mathrm{mM}$ potassium phosphate buffer, $\mathrm{pH} 2.5$ ) instead of guanidine hydrochloride. To speed up the solubilization process, the samples were incubated at $37^{\circ} \mathrm{C}$ in a water bath for $60 \mathrm{~min}$. The final solution was centrifuged to remove any insoluble material. The carbonyl content was calculated from the absorbance measurement at $375 \mathrm{~nm}$, using an absorption coefficient $\mathrm{e}=22,000 / \mathrm{M} \times \mathrm{cm}$.

\subsubsection{RNA and DNA analysis of muscle}

The nucleic acid content of muscle was measured based on Moss's protocol (Moss, 1994). In a glass tube, nucleic acids were precipitated from $250 \mathrm{mg}$ of pereopod muscle by using $4 \mathrm{~mL}$ cold $0.22 \mathrm{~N}$ perchloric acid. Samples were then stored at $4{ }^{\circ} \mathrm{C}$ for $15 \mathrm{~min}$, centrifuged at $3000 \times g\left(4^{\circ} \mathrm{C}\right)$ for $10 \mathrm{~min}$, and the supernatant was then discarded. The resulting precipitate was dissolved in $4 \mathrm{~mL} 0.3 \mathrm{~N} \mathrm{KOH}$ while incubating in a hot water bath $\left(38^{\circ} \mathrm{C}\right)$ for about $2 \mathrm{~h}$. DNA was precipitated with $1 \mathrm{~mL}$ cold $2.3 \mathrm{~N}$ perchloric acid and samples were vortexed, stored at $4{ }^{\circ} \mathrm{C}$ for $15 \mathrm{~min}$, and then centrifuged at $3000 \times \mathrm{g}\left(4^{\circ} \mathrm{C}\right)$ for $15 \mathrm{~min}$. RNA was determined by adding $2 \mathrm{~mL}$ orcinol reagent to $1 \mathrm{~mL}$ of the supernatant, which was then incubated in a hot water bath $\left(98\right.$ to $\left.100^{\circ} \mathrm{C}\right)$ for 20 min. RNA samples were cooled to room temperature and read on a spectrophotometer (GBC Cintra 10e) at $665 \mathrm{~nm}$.

The DNA precipitate was dissolved in $5 \mathrm{~mL} 0.3 \mathrm{~N} \mathrm{KOH}$ while incubating in a hot water bath $\left(98\right.$ to $100^{\circ} \mathrm{C}$ ) for $20 \mathrm{~min}$. DNA was determined directly on $1 \mathrm{~mL}$ of the dissolved fraction by adding $3 \mathrm{~mL}$ 
indole reagent to the DNA sample, which was then incubated in a hot water bath (98 to $100{ }^{\circ} \mathrm{C}$ ) for $20 \mathrm{~min}$. Samples were cooled on ice for $5 \mathrm{~min}$, washed twice with $4 \mathrm{~mL}$ chloroform, centrifuged at $3000 \times g$ (room temperature) for $5 \mathrm{~min}$, and read on a spectrophotometer at $490 \mathrm{~nm}$. The RNA standard was yeast bulk RNA (Sigma R6750) and the DNA standard was from calf thymus (Sigma D1501).

\subsection{Statistical analyses}

Data are presented as means \pm standard errors. The effects of starvation and feeding every 15 days (experiment 1 ) and stocking density during starvation (experiment 2) onweight, meat yield, MGI, muscle water, digestive enzymes, energetic reserves, oxidative damage, and nucleic acid content of SKC were analyzed using Generalized Linear Mixed Models (GLMMs) using Info-Stat software (2015) (Zuur et al., 2009; Di Rienzo et al., 2011). The heterogeneous variance structure was modeled, and the most parsimonious model was selected using the Akaike Information Criterion (AIC), and graphical inspection of residual distributions. Post-hoc comparisons were performed using Fisher's LSD test. For all analyses, residuals were analyzed for normality using the Shapiro-Wilks test. The significance level was set at 0.05.

\section{Results}

\subsection{Experiment 1: Effects of feeding crabs every days and starvation}

During this experiment, the overall mortality was $10 \%$ (9 out of 90 crabs) (Laboratory group: three of the crabs fed every 15 days and two of the starved crabs; Sea group: two of the crabs fed every 15 days and two of the starved crabs).

Both starvation and intermittent feeding had low impact on the physiology of male $L$. santolla. When kept at sea and fed every 15 days, crabs showed very slight losses in weight and meat yield, whereas when fed every 15 days or starved, the MGI and water content was unchanged (Table 1). The two latter physiological parameters remained unchanged among treatments regardless of the place where they were performed (at sea or in the laboratory).

Histologically, the structure of the midgut gland of SKC was found to resemble that of other decapod crustaceans (Fig. 1). It was composed of numerous blind end tubules with four main cell types, namely E-, F-, B- and R-cells (Fig. 1A). The histological characteristics of cells were similar to those reported for other decapods such as Penaeus semisulcatus (Al-Mohanna and Nott, 1987). In both the Laboratory and Sea groups, the main changes were observed in starved crabs at 60 days. The principle alterations in the midgut gland were as follows: a) wavy peritubular membrane (Fig. 1C and D); b) hypervacuolation of R-cells (Fig. 1D); c) reduction in the number of F-cells per tubule (Fig. 1C and D); and d) reduction of the size of the vacuole of B-cells (Fig. 1C).

\subsubsection{Activity of digestive enzymes in the midgut gland}

The activities of digestive enzymes (protease and lipase) in crabs fed every 15 days and starved crabs were not affected by the treatment (Table 2) and remained unchanged regardless of whether they were kept at the sea or in the laboratory.

\subsubsection{Energetic reserves of the midgut gland}

Crabs kept at sea consumed glycogen from the midgut gland (Fig. 2A). Crabs fed every 15 days and starved crabs kept at sea reduced their glycogen reserves from 30 to 60 days compared with crabs of the laboratory groups and in the wild condition (Fig. 2A). The glycogen reserves of the pereopod muscle were unchanged among treatments (Fig. 2B).

Starved crabs of both the laboratory and sea groups consumed muscular lipid reserves (Fig. 2D). The muscular lipid concentration of crabs fed every 15 days in the laboratory was lower at 30 and 45 days than that of those fed daily and wild animals, and then recovered at 60 days. Midgut gland lipids remained unchanged, with non-significant variations but high variability, except in the starved crabs kept at sea at 45 days (Fig. 2C).

Protein levels of the midgut gland and pereopod muscle of crabs fed every 15 days and starved crabs were unchanged, regardless of whether the experiment was performed at sea or in the laboratory (Fig. 2E and F), except for the muscle of those kept at sea for 60 days (Fig. 2F).

\subsubsection{Oxidative damage in the midgut gland and muscle}

Protein oxidation remained unchanged (Fig. $3 \mathrm{~A}$ and B) in the midgut gland and muscle, except in the muscle of crabs fed every 15 days and starved crabs kept at sea at 60 days (Fig. 3B). Lipid peroxidation changed differently in the midgut gland and in the pereopod muscle (Fig. 3C and D). Specifically, crabs fed every 15 days and starved crabs held in the laboratory and at sea had lower levels of lipid peroxidation in the midgut gland at 60 days (Fig. 3C), but lower levels of lipid peroxidation in the muscle at 30 days (Fig. 3D). The levels of lipid peroxidation of crabs kept in the laboratory and fed every 15 days were lower at 30 and 45 days, while those of starved crabs were lower at 45 days (Fig. 3D).

Table 1

Physiological parameters of male Lithodes santolla after 30, 45 and 60 days of being fed every 15 days or starved.

\begin{tabular}{|c|c|c|c|c|c|c|c|}
\hline \multirow{2}{*}{$\begin{array}{l}\text { Physiological } \\
\text { parameters }\end{array}$} & \multirow[t]{2}{*}{ Days } & \multirow[t]{2}{*}{ Wild Condition } & \multicolumn{5}{|l|}{ Treatments } \\
\hline & & & Fed & Fed every 15 days & Starvation & $\begin{array}{l}\text { Fed every } \\
15 \text { days }\end{array}$ & Starvation \\
\hline \multirow{3}{*}{$\begin{array}{l}\text { Weight variation } \\
\text { (\%) }\end{array}$} & 0 & - & - & - & - & - & - \\
\hline & 30 & - & $-4.84 \pm 1.84$ & $1.23 \pm 2.46$ & $-1.60 \pm 2.73$ & $-1.37 \pm 1.48$ & $5.05 \pm 2.65$ \\
\hline & 45 & - & $-1.09 \pm 2.50$ & $-1.32 \pm 1.23$ & $-3.95 \pm 2.08$ & $-3.52 \pm 3.38$ & $1.77 \pm 7.07$ \\
\hline \multirow{3}{*}{$\begin{array}{l}\text { Meat } \\
\quad \text { yield (\%) }\end{array}$} & 30 & - & $50.08 \pm 1.96$ & $56.20 \pm 1.73$ & $54.22 \pm 1.51$ & $53.6 \pm 2.14$ & $55.27 \pm 1.07$ \\
\hline & 45 & - & $53.21 \pm 1.37$ & $53.26 \pm 1.10$ & $52.87 \pm 1.22$ & $50.46 \pm 1.54$ & $51.97 \pm 2.70$ \\
\hline & 60 & - & $55.44 \pm 1.29^{\mathrm{a}}$ & $54.10 \pm 1.68^{\mathrm{a}}$ & $53.50 \pm 1.04^{\mathrm{a}}$ & $46.73 \pm 1.41^{\mathrm{b}}$ & $59.93 \pm 12.76^{\mathrm{a}}$ \\
\hline \multirow[t]{4}{*}{ Midgut gland Index (\%) } & 0 & $5.37 \pm 0.62$ & - & - & - & - & - \\
\hline & 30 & - & $4.80 \pm 0.60$ & $4.62 \pm 0.39$ & $4.22 \pm 0.60$ & $4.00 \pm 0.73$ & $4.97 \pm 1.47$ \\
\hline & 45 & - & $5.16 \pm 0.62$ & $3.54 \pm 0.48$ & $3.78 \pm 0.48$ & $5.66 \pm 1.19$ & $3.95 \pm 0.71$ \\
\hline & 60 & - & $4.64 \pm 0.37$ & $4.66 \pm 0.46$ & $4.59 \pm 0.39$ & $4.43 \pm 0.90$ & $3.63 \pm 0.59$ \\
\hline
\end{tabular}



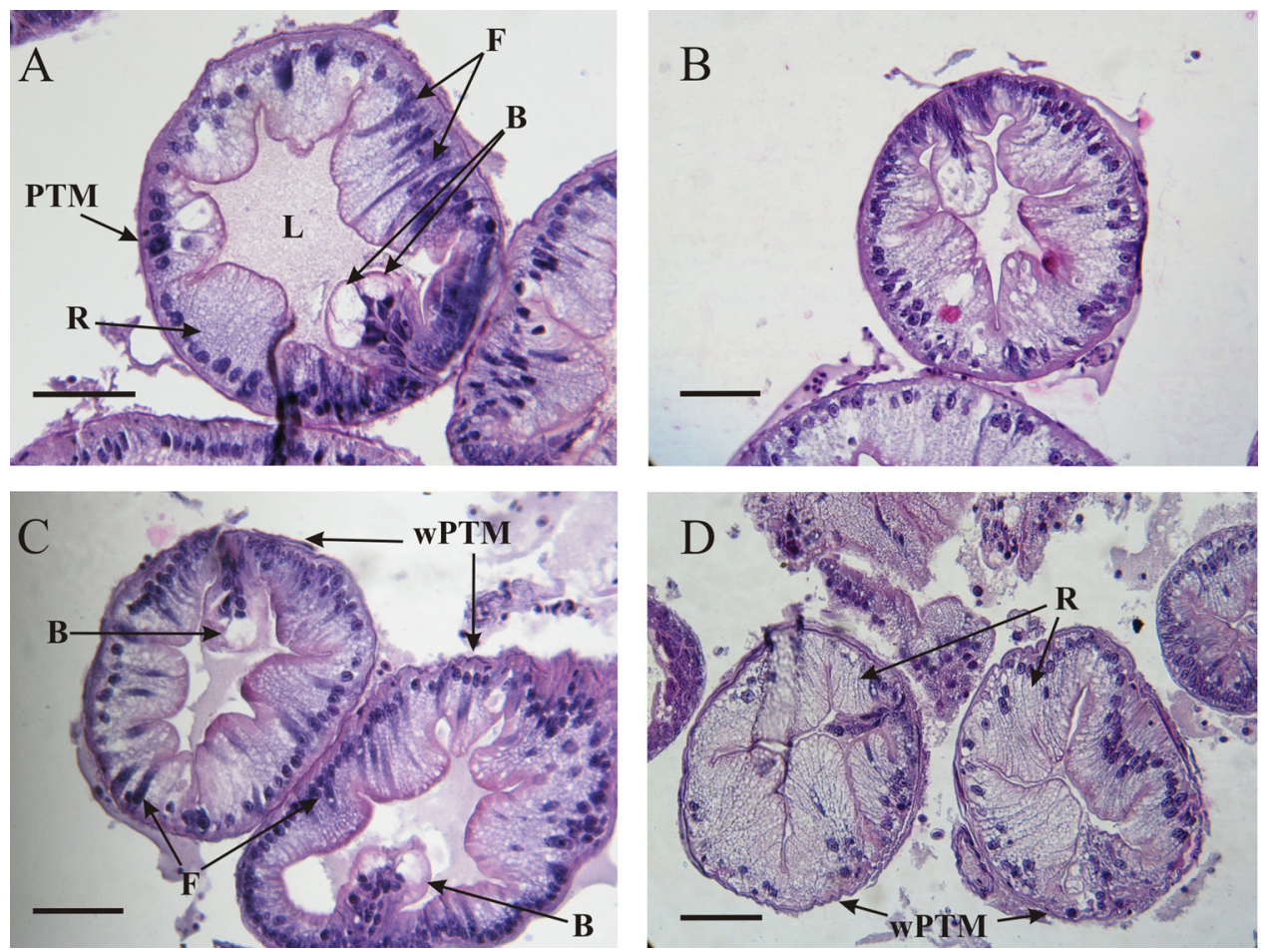

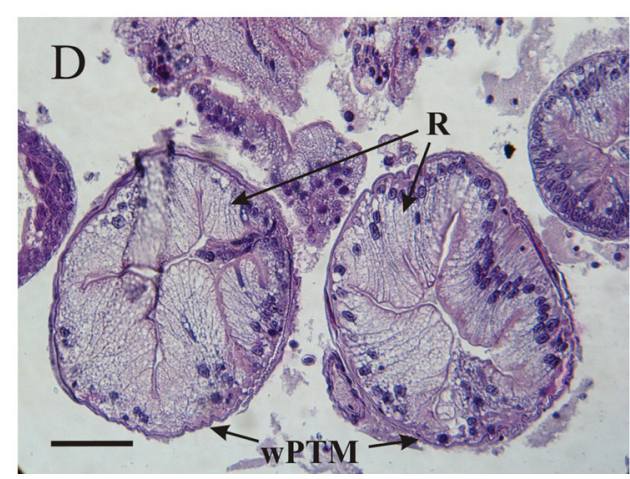

Fig. 1. Histological sections of the midgut gland of Lithodes santolla male crabs. A): wild crab. B) Starvation at sea after 30 days: no structural changes were observed. C) Starvation at sea after 60 days: wavy peritubular membrane (wPTM), reduction in the number of F-cells per tubule, and reduction of vacuole B-cells. D) Starvation in the laboratory after 60 days: wavy peritubular membrane, hypervacuolation of R-cells, and reduction in the number of F-cells per tubule. All scale bars: $=125 \mu \mathrm{m}$. B: B-cell; F: F-cell; L: tubular lumen; PTM; peritubular membrane; R: R-cell.

Table 2

Activity of digestive enzymes in the midgut gland of male Lithodes santolla after 30, 45 and 60 days of being fed every 15 days or starved.

\begin{tabular}{|c|c|c|c|c|c|c|c|}
\hline \multirow[t]{3}{*}{ Digestive Enzymes } & \multirow[t]{3}{*}{ Days } & \multirow[t]{3}{*}{ Wild Condition } & \multicolumn{5}{|l|}{ Treatments } \\
\hline & & & \multicolumn{3}{|l|}{ Laboratory } & \multicolumn{2}{|l|}{ Sea } \\
\hline & & & Fed & Fed every 15 days & Starvation & Fed every 15 days & Starvation \\
\hline \multirow{4}{*}{$\begin{array}{l}\text { Protease } \\
\qquad \text { (U/mg protein) }\end{array}$} & 0 & $5.91 \pm 0.32$ & - & - & - & - & - \\
\hline & 30 & - & $4.40 \pm 0.28$ & $4.90 \pm 0.30$ & $5.20 \pm 0.50$ & $5.11 \pm 0.42$ & $4.87 \pm 0.19$ \\
\hline & 45 & - & $4.46 \pm 0.62$ & $4.83 \pm 0.77$ & $4.96 \pm 0.69$ & $4.79 \pm 0.37$ & $4.86 \pm 0.38$ \\
\hline & 60 & - & $5.13 \pm 0.53$ & $5.40 \pm 0.46$ & $4.55 \pm 0.41$ & $3.76 \pm 0.45$ & $4.60 \pm 0.29$ \\
\hline \multirow{4}{*}{$\begin{array}{l}\text { Lipase } \\
\qquad(\mathrm{U} / \mathrm{mg} \text { protein) }\end{array}$} & 0 & $16.36 \pm 2.27$ & - & - & - & - & - \\
\hline & 30 & - & $15.00 \pm 2.54$ & $15.51 \pm 1.56$ & $15.04 \pm 3.49$ & $11.73 \pm 1.15$ & $16.16 \pm 1.66$ \\
\hline & 45 & - & $15.21 \pm 1.62$ & $21.08 \pm 3.37$ & $17.28 \pm 2.34$ & $16.75 \pm 1.83$ & $18.20 \pm 2.63$ \\
\hline & 60 & - & $18.85 \pm 4.07$ & $12.19 \pm 2.95$ & $14.10 \pm 3.18$ & $13.56 \pm 4.14$ & $15.86 \pm 2.21$ \\
\hline
\end{tabular}

Different letters indicate statistical differences $(\mathrm{p}<0.05)$.

\subsubsection{RNA and DNA analysis of muscle}

The RNA:DNA ratio in crabs fed every 15 days and starved crabs remained unchanged regardless of whether the experiment was performed at sea or in the laboratory (Fig. 3A).

\subsection{Experiment 2: Effect of stock density during starvation}

All animals survived experiment 2. The MGI changed after 30 days of starvation and at different stocking density conditions (Table 3). Crabs stocked at different densities showed a lower MGI than those in the wild. Crabs slightly reduced their weight, but this variation was not statistically significant. During this experiment, the meat yield and water content of the crabs were unchanged compared to those of wild crabs (Table 3).

\subsubsection{Activity of digestive enzymes in the midgut gland}

The activities of digestive enzymes (lipase and protease) were affected by the stocking density condition (Table 4). Specifically, lipase activity decreased at all stocking densities tested at 30 days, whereas proteinase activity was similar to that of wild crabs (Table 4).

\subsubsection{Energetic reserves of the midgut gland and muscle}

Glycogen reserves of the midgut gland decreased with the stocking density (Fig. 5A), whereas lipid levels decreased at low and medium densities (Fig. 5C). In contrast, protein reserves increased in the three stocking density conditions (Fig. 5E). On the other hand, in the pereopod muscle, glycogen, lipid and protein reserves remained unchanged in starved crabs at the different stocking densities (Fig. 5B, D and $\mathrm{F}$ ).

\subsubsection{Oxidative damage in the midgut gland and muscle}

At different stocking densities, the protein oxidation in the muscle increased, whereas that in the midgut gland was not affected (Fig. 6A and B). In contrast, the lipid peroxidation level in the midgut gland decreased with the stocking density condition (Fig. 6C), whereas that in the muscle remained unchanged (Fig. 6D).

\subsubsection{RNA:DNA ratio of the muscle}

The RNA:DNA ratio of the muscle was lower under the experimental densities than in the wild (Fig. 4B). 

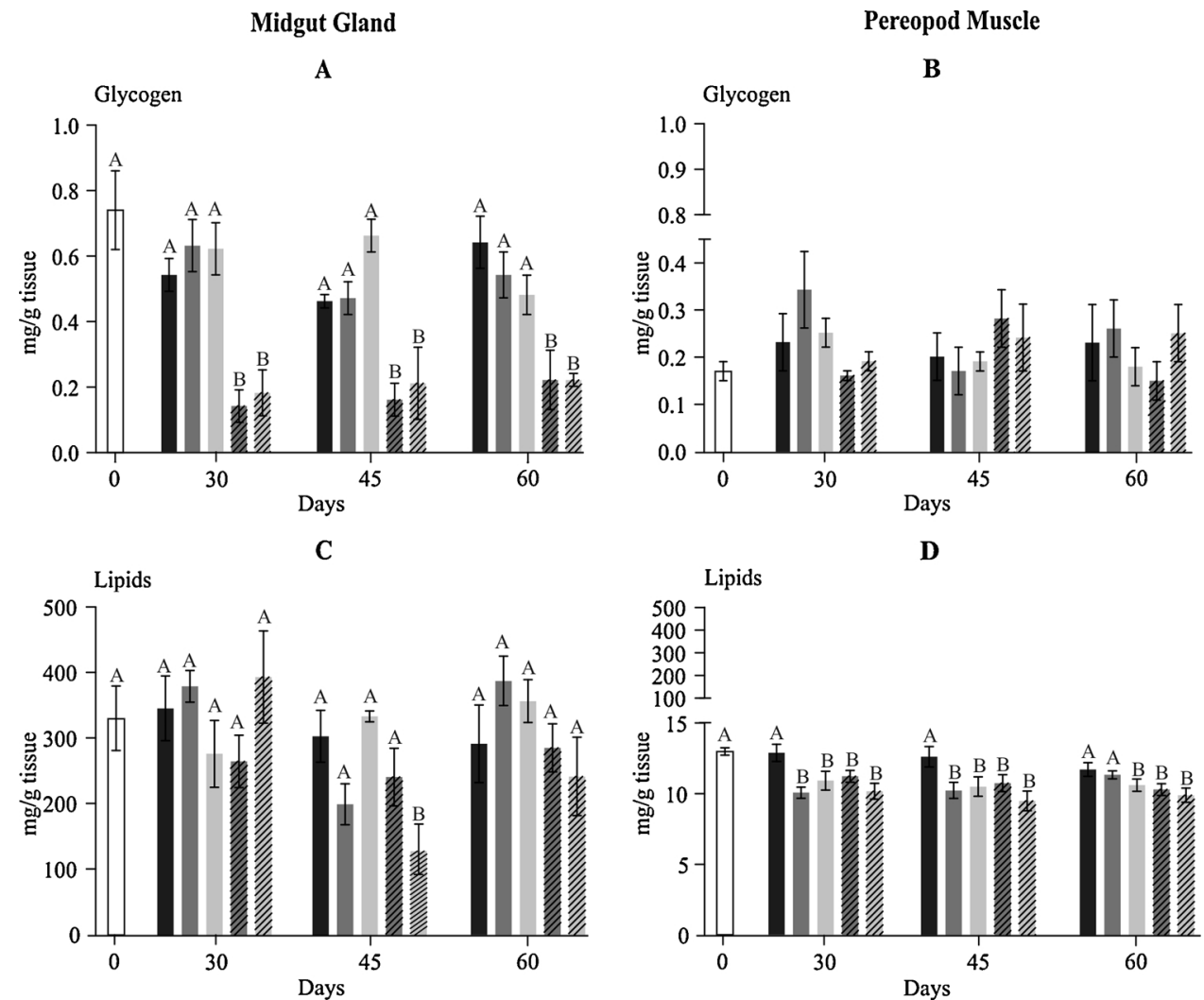

E

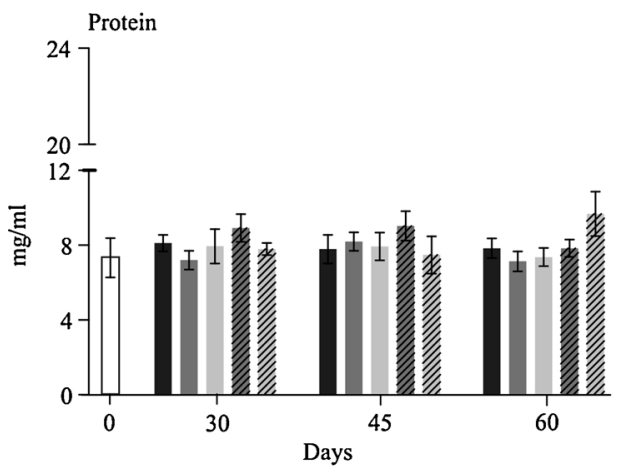

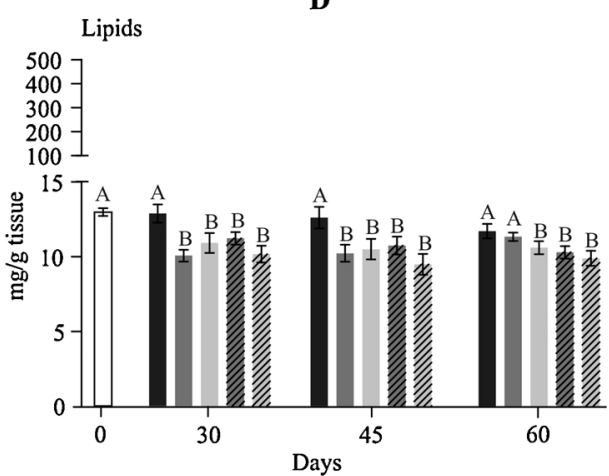

F

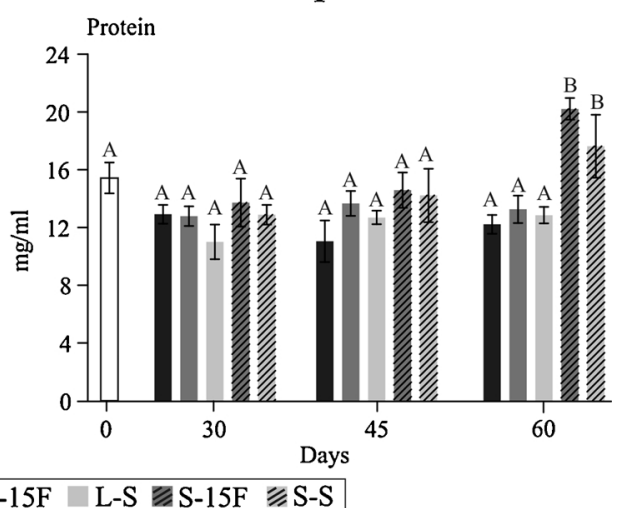

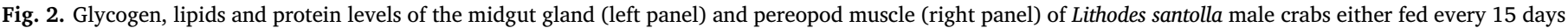

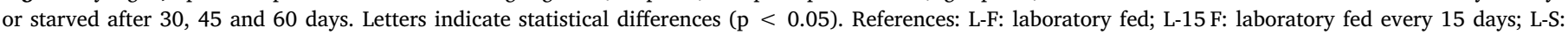
laboratory starvation; S-15 F: sea fed every 15 days; S-S: sea starvation.

\section{Discussion}

The results of this study showed that male SKC can tolerate extended periods without food and high-density conditions without lowering their body mass or meat yield. According to the physiological parameters measured, their commercial condition would not be affected and they could be held for a long time and thus be available alive in the market. Specifically, our results demonstrate a glycogen reduction of the midgut gland in the sea treatment and a muscle lipid decrease in both the laboratory and sea treatments. These responses did not lead to a reduction in the midgut gland mass or increased the water content of the muscle. Under different stocking densities, overall, there was a reduction of the MGI, glycogen, lipase and lipid peroxidation in the midgut gland; the pereopod muscle showed an increase in protein oxidation and a decrease in the RNA:DNA ratio.

In general, as a response to starvation, the reduction in the midgut gland mass is due to changes in the energetic reserve (Sacristán et al.,
2017). In our stocking density experiment, such a drop in the MGI was coincident with a decline in glycogen in male crabs. In contrast, the midgut gland mass was unchanged in crabs fed every 15 days and starved crabs kept at sea (Table 1), despite the depletion observed in glycogen reserves (Fig. 2). In these crabs, almost $80 \%$ of the glycogen levels were consumed after 30 days (Fig. 2A) and then gradually consumed as crab density increased (Fig. 5A). Our results agree with the hypothesis that marine decapods likely use glycogen reserves as a primary energy source during starvation (Sacristán et al., 2017).

According to our results, exercise could have caused muscular lipolysis. In our experiments, both in the laboratory and at sea, the crabs fed every 15 days and starved crabs showed a muscular lipid reserve reduction. In contrast, muscular lipids were unchanged at different stocking densities, but lipids did decrease in the midgut gland at low and medium densities. The latter densities or their maintenance solitarily allowed the crabs to wander around the container, and this might have caused muscular lipid reduction. This result agrees with that 


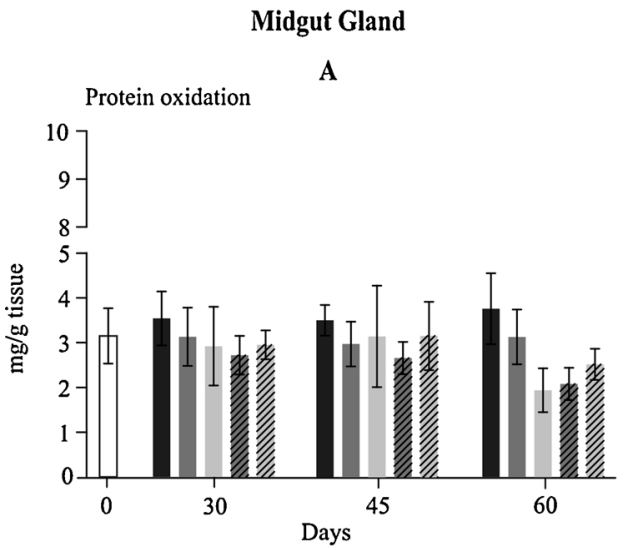

C

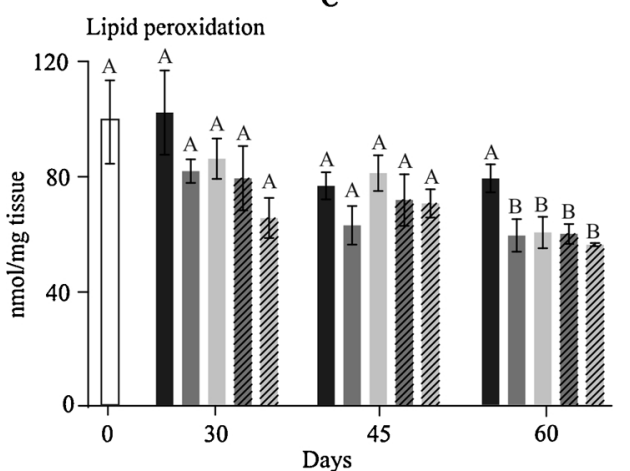

Pereopod Muscle

B

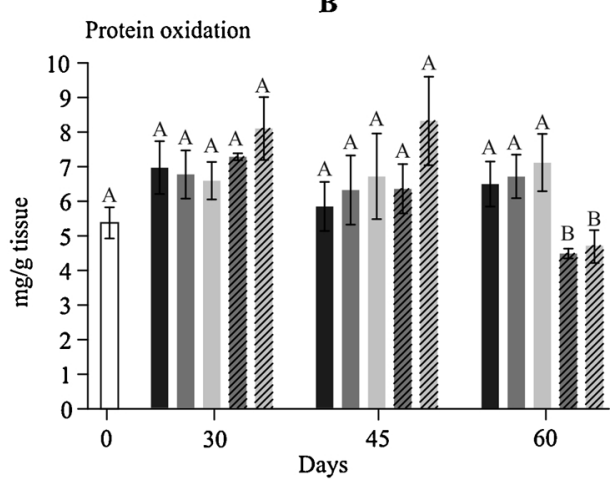

D

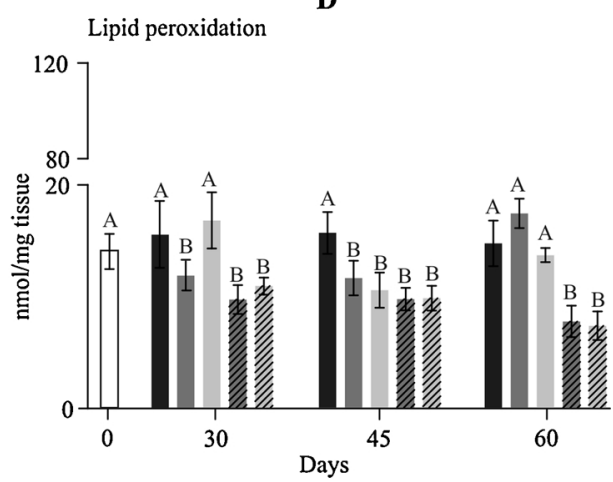

Fig. 3. Protein oxidation and lipid peroxidation of the midgut gland (left panel) and pereopod muscle (right panel) of Lithodes santolla male crabs either fed every 15 days or starved after 30, 45 and 60 days. Letters indicate statistical differences $(\mathrm{p}<0.05)$. References: LF: laboratory fed; L-15 F: laboratory fed every 15 days; L-S: laboratory starvation; S-15 F: sea fed every 15 days; S-S: sea starvation.

$\square$ Wild condition $\square$ L-F $\square$ L-15F $\square$ L-S $\approx$ S-15F $\geqslant$ S-S

observed in experiment 1 (crabs fed every 15 days and starved crabs) in which crabs kept in individual plastic containers also showed a muscular lipid reduction. At low and medium densities, the low lipid level of the midgut gland could be explained by the mobilization for the maintenance of the muscular lipid reserve.

Proteins either remained constant (experiment 1) or increased (experiment 2), evidenced by the absence of catabolism. The absence of changes in water content and the non use of proteins indicate that the flesh in legs did not change and crabs would have similar organoleptic properties. Hence, crabs can be sold without a loss in yield and taste. Free amino acids play a marked role in taste. Changes in the concentration of free amino acids in the crab meat, e.g. aspartic and glutamic acids, amino acids with a hydrophilic chain, and glycine and alanine, can contribute to an acid, bitter or sweet taste, respectively (Shao et al., 2014). On the other hand, a prudent use of protein in starvation periods may be an adaptive strategy to avoid the use of high costly macromolecules (Sacristán et al., 2017). Furthermore, the catabolism of the protein and free amino acid pool might lead to enzyme proteolysis and the lack of amino acids for the de novo synthesis of enzymes, which could be essential in different metabolic processes to obtain energy through different pathways (Sacristán et al., 2017).
Protease activity was not affected by the feeding treatments (feeding every 15 days and starvation) or the stocking density, but, differently, lipase decreased at the three experimental densities. The protease activity of crabs of the feeding treatments (feeding every 15 days and starvation) was similar to that of crabs of the wild condition and fed animals. This could indicate that proteases might be stored inside digestive gland cells until food is ingested. One of the main proteases of the crustacean midgut gland is trypsin (Tsai et al., 1986). Trypsinogen, the precursor of trypsin, is secreted as a result of ingestion in both fed and starved shrimps Penaeus vannamei (Sainz et al., 2004). On the other hand, the reduction in lipase activity observed in starved crabs at different stocking densities agrees with previous studies, where the activity and expression of lipase messengers decreases during fasting (Yudkovski et al., 2007; Rivera-Pérez and García-Carreño, 2011; Calvo et al., 2013; Sacristán et al., 2014, 2016). By contrast, the results of our stocking density experiment differ from those of the starvation experiment, since lipase activity in crabs fed every 15 days and starved crabs showed no differences after 30,45 or 60 days in the laboratory and sea experiments. One possible explanation is that the experiments were performed in different years and wild animals had different lipase activity levels. The initial animal state could be conditioning their

Table 3

Physiological parameters of male Lithodes santolla at different stocking densities after 30 days of starvation.

\begin{tabular}{|c|c|c|c|c|}
\hline \multirow{2}{*}{$\begin{array}{l}\text { Physiological } \\
\text { parameters }\end{array}$} & \multicolumn{4}{|l|}{ Treatments } \\
\hline & Wild Condition & $\begin{array}{l}\text { Low } \\
\left(35 \text { crabs } \mathrm{m}^{-3}\right)\end{array}$ & $\begin{array}{l}\text { Medium } \\
\left(69 \text { crabs m }^{-3}\right)\end{array}$ & $\begin{array}{l}\text { High } \\
\left(115 \text { crabs } \mathrm{m}^{-3}\right)\end{array}$ \\
\hline Weight variation (\%) & - & $-2.58 \pm 0.43$ & $-3.55 \pm 1.29$ & $-3.63 \pm 0.37$ \\
\hline Meat yield (\%) & $55.02 \pm 1.02$ & $55.26 \pm 0.49$ & $55.89 \pm 1.19$ & $54.81 \pm 0.53$ \\
\hline Midgut gland Index (\%) & $5.72 \pm 0.47^{\mathrm{a}}$ & $3.87 \pm 0.13^{\mathrm{b}}$ & $4.09 \pm 0.31^{\mathrm{b}}$ & $4.10 \pm 0.21^{\mathrm{b}}$ \\
\hline Water contents (\%) & $74.78 \pm 2.63$ & $78.17 \pm 0.11$ & $78.41 \pm 0.58$ & $77.83 \pm 0.70$ \\
\hline
\end{tabular}

Different letters indicate statistical differences $(\mathrm{p}<0.05)$. 
Table 4

Activity of digestive enzymes of the midgut gland of male Lithodes santolla at different stocking densities during 30 days of starvation.

\begin{tabular}{|c|c|c|c|c|c|}
\hline \multirow[t]{2}{*}{ Digestive Enzymes } & \multirow[t]{2}{*}{ Days } & \multicolumn{4}{|l|}{ Treatments } \\
\hline & & Wild Condition & $\begin{array}{l}\text { Low } \\
\text { density }\end{array}$ & Medium density & High density \\
\hline Protease & 0 & $6.80 \pm 0.95$ & - & - & - \\
\hline (U/mg protein) & 30 & - & $7.85 \pm 1.05$ & $7.53 \pm 1.01$ & $7.86 \pm 1.23$ \\
\hline Lipase & 0 & $47.63 \pm 11.34^{\mathrm{a}}$ & - & - & - \\
\hline (U/mg protein) & 30 & - & $24.23 \pm 2.39^{\mathrm{b}}$ & $26.97 \pm 2.19^{\mathrm{b}}$ & $27.47 \pm 4.86^{\mathrm{b}}$ \\
\hline
\end{tabular}

Different letters indicate statistical differences $(\mathrm{p}<0.05)$.

\section{Pereopod Muscle}

A

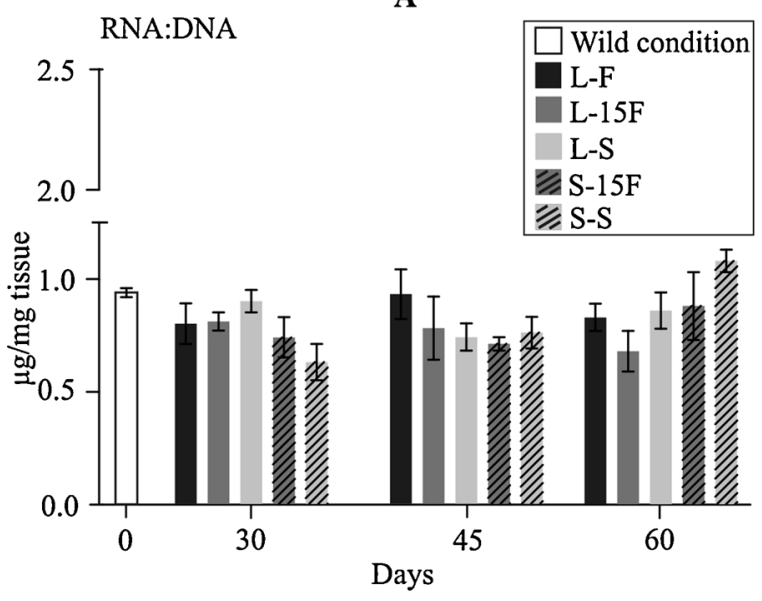

B

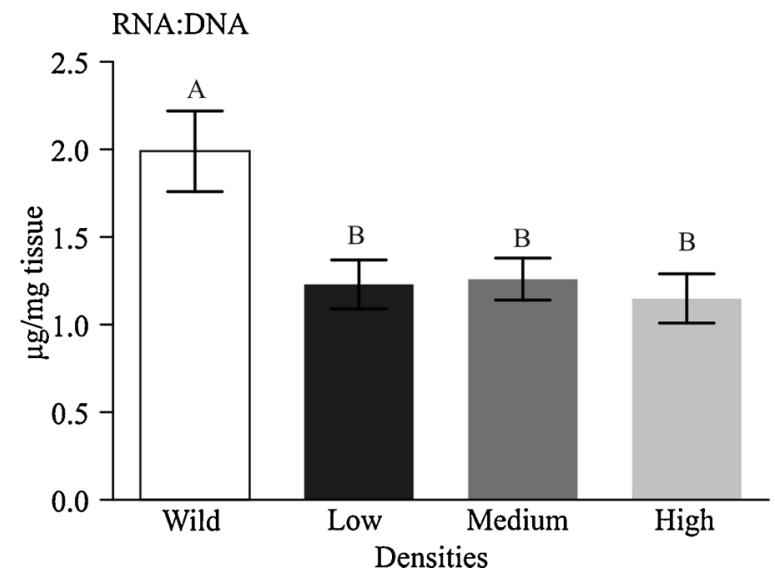

Fig. 4. RNA:DNA ratio of pereopod muscle of Lithodes santolla male crabs either fed every 15 days or starved after 30, 45 and 60 days (A), and under different stocking densities (B). Letters indicate statistical differences $(\mathrm{p}<0.05)$. References: L-F: laboratory fed; L-15 F: laboratory fed every 15 days; L-S: laboratory starvation; S-15 F: sea fed every 15 days; S-S: sea starvation.

physiological response to the effects of starvation and stocking density. Therefore, we suggest that to avoid misinterpretation of experimental results, any assay involving wild animals in confinement conditions must consider animals in wild condition ("wild control") to compare them with the experimental control.

In this study, crabs had different patterns of oxidative damage in the midgut gland and muscle as a response to the effects of the feeding treatments (feeding every 15 days and starvation) and stocking density. Specifically, protein oxidation in starved crabs did not change and depended on the protein concentration. At different stocking densities, muscle protein oxidation increased, but remained constant in the midgut gland. This trend was contradictory to the variation in protein reserves. On the other hand, lipid peroxidation levels coincided with the lipid reserve pattern in both experiments.

The meat quality of $L$. santolla was probably not affected by starvation or different stocking densities after 30 days. The small biochemical fluctuations of the meat, i.e., the small fluctuation in lipid and protein concentration, water content, protein oxidation and lipid peroxidation levels, would not affect its texture, taste or nutritional value. In contrast, changes in the concentration of free amino acids (Shao et al., 2014) and oxidative reactions in the meat are the most important factors in quality loss (Soyer et al., 2010). In Paralomis granulosa, after anoxia ( $6 \mathrm{~h}$ of air exposure) and re-submersion, crabs showed an undamaged muscle, but exhibited physiologically impaired midgut gland and gills, although this damage was quickly reversed once the animals were returned to the water (Romero et al., 2011). The meat flavor did not change after air exposure and $24 \mathrm{~h}$ of recovery in a palatability assay of $P$. granulosa flesh (Romero et al., 2011). In L. santolla, after $24 \mathrm{~h}$ of air exposure without re-submersion muscle lipid peroxidation was increased (Lorenzo pers. com.).

According to the results observed regarding the RNA:DNA ratio, the three stocking densities were stressful for $L$. santolla. Under changing environmental situations, the amount of DNA is stable within somatic cells (Bulow, 1987), whereas the amount of RNA directly involved in protein synthesis is known to vary with age, life-stage, organism size, disease-state and changing environmental conditions (Bulow, 1970). Thus, organisms in good condition tend to have higher RNA:DNA ratios than those in poor condition (Chícharo and Chícharo, 2008).

The results of the present study showed that $L$. santolla could be kept at high stocking densities. When holding live animals, one of the most important factors to consider is their survival and meat yield. In the Beagle Channel, fishers keep crabs inside their fishing traps placed on the sea bottom at a density of 65 animals $\mathrm{m}^{-3}$ (personal observation). Contrary to what could be expected, mortality was very low in our experiments $(10 \%$ in the starvation experiment and $0 \%$ in the stocking density experiment). In general, mortality increases as stocking density increases. For example, high mortality ranging from $26 \%$ to $36 \%$ was observed in fed Chionoecetes opilio kept at stocking densities of 200, 150 and $100 \mathrm{~kg} \mathrm{~m}^{-3}$, whereas in starved animals kept at $50 \mathrm{~kg} \mathrm{~m}^{-3}$, mortality was $14 \%$ of after 30 days (Siikavuopio et al., 2017). Similar results were observed in Paralithodes camtschaticus, in which the highest mortality was observed at the highest stocking density ( $17 \%$ mortality at $200 \mathrm{~kg} \mathrm{~m}^{-3}$ ) (Siikavuopio et al., 2016).

Male $L$. santolla can tolerate 60 days of food deprivation without lowering their meat yield. Water content in experimental animals (crabs fed every 15 days, starved crabs, and stocking density experiment) was constant. The catabolism of energetic reserves (e.g., glycogen and lipid) and midgut gland mass (stocking density experiment) may have caused an increase in water content, but this was not observed in our experiments. These results agree with the histological analysis of the midgut gland, which showed wavy peritubular membrane, hypervacuolation of R-cells, reduction in the number of F-cells per tubule, and reduction of vacuole B-cells. Moreover, crabs only 

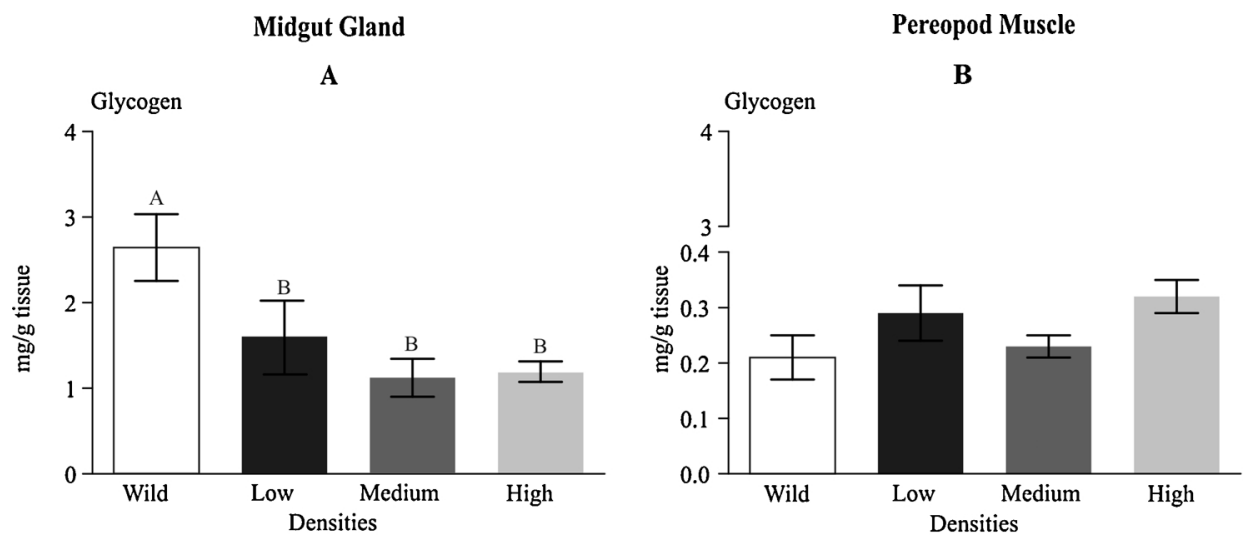

C

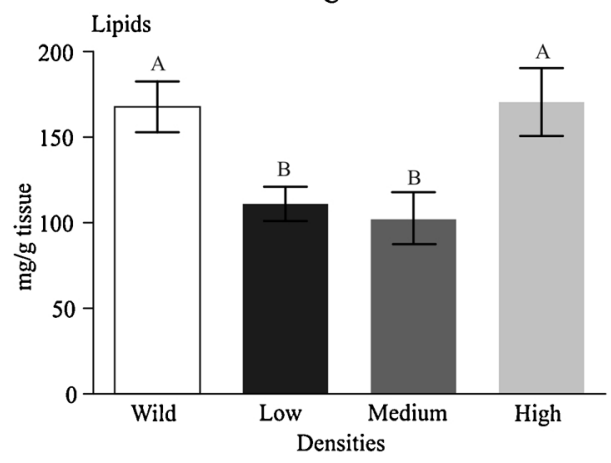

$\mathbf{E}$

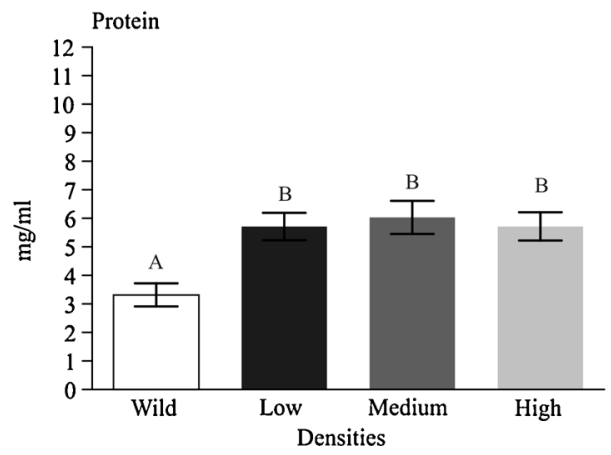

D

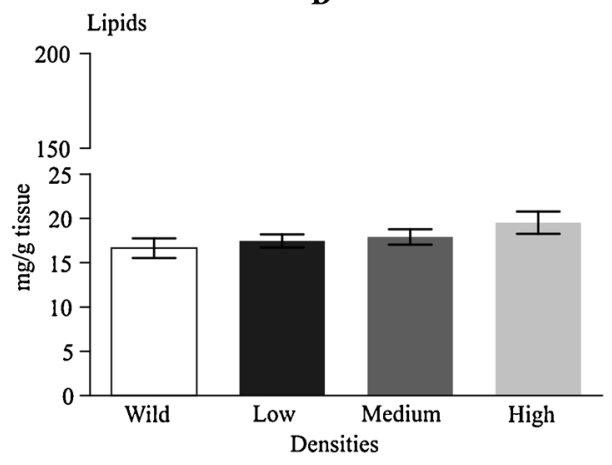

F

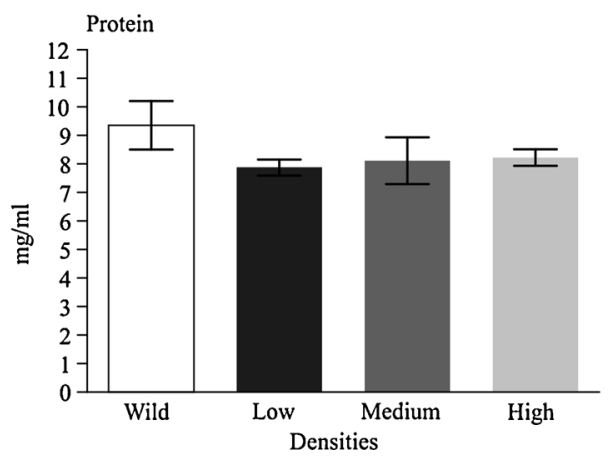

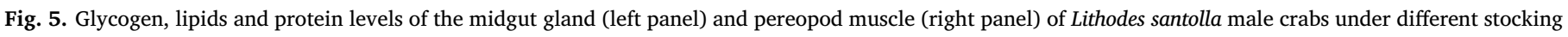
densities. Different letters indicate statistical differences $(p<0.05)$.

reduced $3 \%$ of their wet mass, and there would be no loss in the meat. Hence, keeping animals for one month before trade revenues in the $L$. santolla market chain will still maintain the product's high quality. In starved $C$. opilio and $P$. camtschaticus kept at different stocking densities, crabs only lost on average $17 \mathrm{~g}$ of the $650 \mathrm{~g}$ average mass, and that the meat content reduction was between $5 \%$ and $14.6 \%$ after 30 or 56 days respectively (Siikavuopio et al., 2016, 2017). In a recent study in $P$. camtschaticus, the reduction of meat content (46\%) and yield of red king crab decreased during a holding period of 92 days at $5{ }^{\circ} \mathrm{C}$ without food (Lorentzen et al., 2019).

Our results suggest that male $L$. santolla have physiological features that make them suitable to be maintained in indoor holding tanks. They tolerate relatively high stocking densities, have starvation resistance, low mortality, and endure 60 days of food deprivation without lowering their meat yield or body mass. However, the disadvantages of maintaining crabs alive in holding facilities are: the available space, the maintenance of the seawater system (e.g., equipment for seawater monitoring, UV-sterilization, pump, filters, chiller system, labor costs), and losses of the water quality by animal excretion. Therefore, a cost/ benefit analysis should be undertaken to compare the revenue versus the increased cost of maintaining king crabs in indoor holding tanks. Alternatively, their holding at sea, in waters far from the influence of a city, seems to be more convenient, because of its low maintenance cost and comparable to our experiment with cages at sea.

In conclusion, long-term holding of SKC $L$. santolla males under starvation allows them to be retailed off-season. Southern king crabs landed by the fishery could be kept under fasting conditions for periods varying from a few days to two months under indoor facilities with a minimum loss of meat yield and quality.

\section{Competing interests}

The authors declare that there are no conflicts of interests.

\section{Acknowledgements}

We thank Mrs. María Luján Pagnossin and Mr. Marcelo Pérez for the field assistance. We also thank María Victoria Gonzalez Eusevi for supervising the English writing of the final version of the manuscript. We also thank Argentinian public politics for education, science, and 
Midgut Gland

A

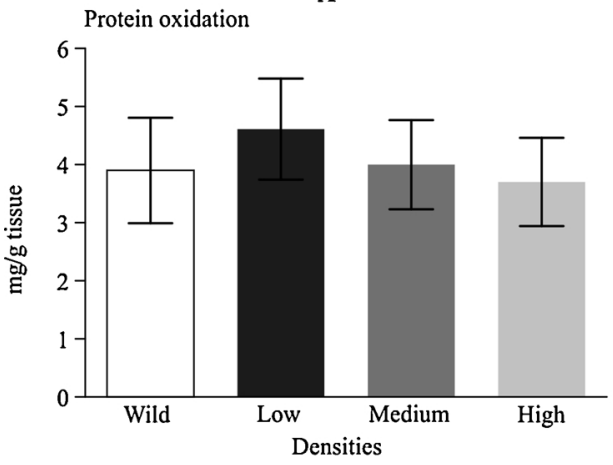

C

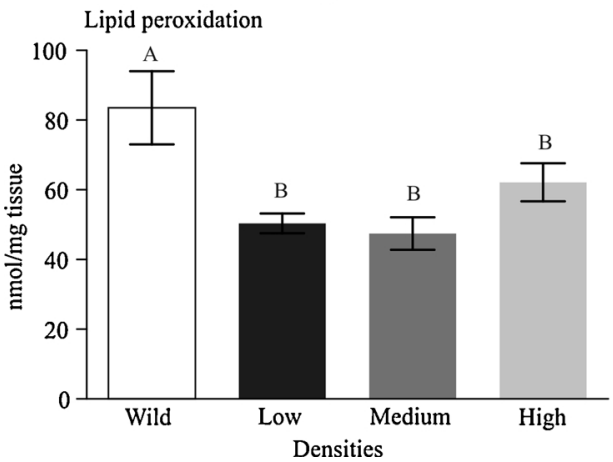

Pereopod Muscle

B

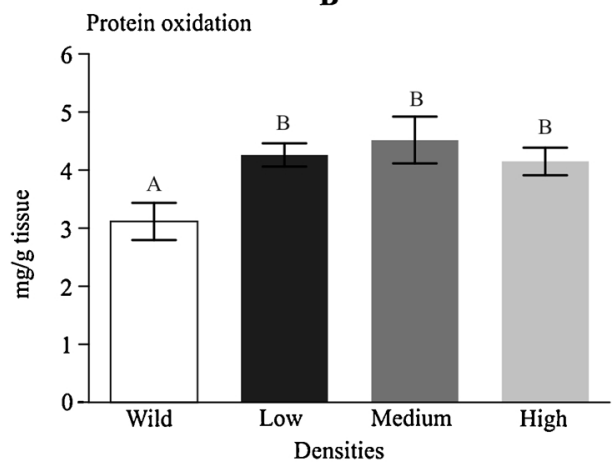

D

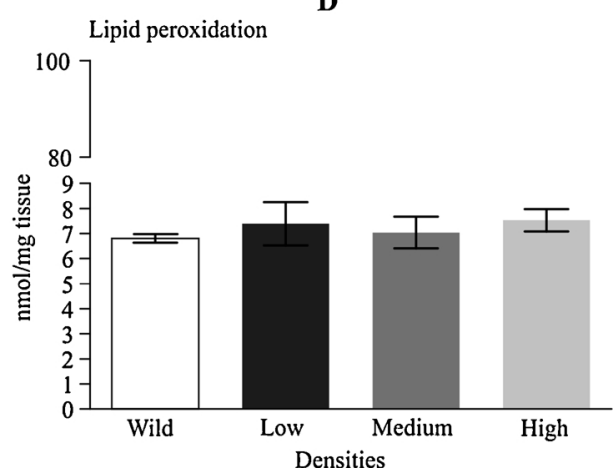

Fig. 6. Protein oxidation and lipid peroxidation of the midgut gland (left panel) and pereopod muscle (right panel) of Lithodes santolla male crabs under different stocking densities. Different letters indicate statistical differences $(\mathrm{p}<0.05)$.

technology during the period of 2003-2015. This work was supported by the Fondo para la Investigación Científica y Tecnológica of Argentina (grants numbers PICT 2012-0554; 2016-0142 to G.A.L. and 2015-2968 to H.J.S.); and the Universidad Nacional de Mar del Plata (projects $772 / 16$ and $773 / 16$ to A.V.F.G).

\section{References}

Al-Mohanna, S., Nott, J.M., 1987. M-'midget'cells and moult cycle in Penaeus semisulcatus (Crustacea: Decapoda). J. Mar. Biol. Assoc. U. K. 67, 803-813.

Anger, K., Hayd, L., 2009. From lecithotrophy to planktotrophy: ontogeny of larval feeding in the Amazon River prawn Macrobrachium amazonicum. Aquat. Biol. 7, 19-30.

Ansaldo, M., Sacristán, H., Wider, E., 2007. Does starvation influence the antioxidant status of the digestive gland of Nacella concinna in experimental conditions? Comp. Biochem. Physiol. C 146, 118-123.

Bradford, M.M., 1976. A rapid and sensitive method for the quantitation of microgram quantities of protein utilizing the principle of protein-dye binding. Anal. Biochem. 72, 248-254.

Buege, J.A., Aust, S.D., 1978. Microsomal lipid peroxidation. Methods Enzymol. 52, 302-310.

Bulow, F.J., 1970. RNA-DNA ratios as indicators of recent growth rates of a fish. J. Fish. Board Can. 27, 2343-2349.

Bulow, F., 1987. RNA-DNA ratios as indicators of growth in fish: a review. In: Summerfeld, R.C., Hall, G.E. (Eds.), Age and Growth in Fish. Iowa State University Press, Ames, Iowa, pp. 45-64.

Caceci, T., Neck, K.F., Lewis, D.D.H., Sis, R.F., 1988. Ultrastructure of the hepatopancreas of the pacific white shrimp, Penaeus vannamei (Crustacea: Decapoda). J. Mar. Biol. Assoc. U. K. 68, 323-337.

Calvo, N.S., Stumpf, L., Pietrokovsky, S., López Greco, L.S., 2011. Early and late effects of feed restriction on survival, growth and hepatopancreas structure in juveniles of the red claw crayfish Cherax quadricarinatus. Aquaculture 319, 355-362.

Calvo, N.S., Tropea, C., Anger, K., López Greco, L.S., 2012. Starvation resistance in juvenile freshwater crayfish. Aquatic Biol. 16, 287-297.

Calvo, N.S., Stumpf, L., Sacristán, H.J., López Greco, L.S., 2013. Energetic reserves and digestive enzyme activities in juveniles of the red claw crayfish Cherax quadricarinatus nearby the point-of-no-return. Aquaculture 416, 85-91.

Chícharo, M.A., Chícharo, L., 2008. RNA: DNA ratio and other nucleic acid derived indices in marine ecology. Int. J. Mol. Sci. 9, 1453-1471.

Di Rienzo, J.A., Casanoves, F., Balzarini, M.G., Gonzalez, L., Tablada, M., Robledo, C.W., 2011. InfoStat versión 2017. Grupo InfoStat, FCA, Universidad Nacional de Córdoba,
Argentina.

Díaz, A.C., Sousa, L.G., Petriella, A.M., 2010. Functional cytology of the hepatopancreas of Palaemonetes argentinus (Crustacea, Decapoda, Caridea) under osmotic stress. Braz. Arch. Biol. Technol. 53, 599-608.

Fagan, J.M., Sleczka, B.G., Sohar, I., 1999. Quantitation of oxidative damage to tissue proteins. Int. J. Biochem. Cell Biol. 31, 751-757.

FAO, 2017. The State of World Fisheries and Aquaculture (SOFIA). FAO, Fisheries and Aquaculture Department, Rome, Italy.

Folch, J., Lees, M., Sloane-Stanley, G., 1957. A simple method for the isolation and purification of total lipids from animal tissues. J. Biol. Chem. 226, 497-509.

Franceschini-Vicentini, I.B., Ribeiro, K., Papa, L.P., Marques Junior, J., Vicentini, C.A Valenti, P.M.C.M., 2009. Histoarquitectura del hepatopáncreas del camarón de la amazonia Macrobrachium amazonicum. Int. J. Morphol. 27, 121-128.

Frings, C.S., Dunn, R.T., 1970. A colorimetric method for determination of total serum lipids based on the sulfo-phospho-vanillin reaction. Am. J. Clin. Path. 53, 89-91.

García-Carreño, F.L., 1992. The digestive proteases of langostilla (Pleuroncodes planipes, Decapoda): their partial characterization, and the effect of feed on their composition. Comp. Biochem. Physiol. B 103, 575-578.

Gibson, R., Barker, P., 1979. The decapod hepatopancreas. Oceanogr. Mar. Biol. Ann. Rev. 17, 285-346.

Hjelset, A.M., Sundet, J.H., 2004. Sesongmessig variasjoner i fyllingsgrad hos kongekrabbe fra Varangerfjorden, Finnmark.

Icely, J., Nott, J., 1992. Digestion and absorption: digestive system and associated organs. Microsc. Anat Invertebr. 10, 147-207.

James, P., Vasilyev, R., Siikavuopio, S., Kovatcheva, N., Samuelsen, T., Mundheim, H. Carlehög, M., 2013. The effects of varying the percentage of herring versus salmon protein in manufactured diets on the survival, meat content, hepatosomatic index and meat sensory quality of adult red king crab Paralithodes camtschaticus held in captivity. Aquaculture 416, 390-395.

Jones, P., Obst, J., 2000. Effects of starvation and subsequent refeeding on the size and nutrient content of the hepatopancreas of Cherax destructor (Decapoda: Parastacidae). J. Crust. Biol. 20, 431-441.

Li, E., Chen, L., Zeng, C., Yu, N., Xiong, Z., Chen, X., Qin, J.G., 2008. Comparison of digestive and antioxidant enzymes activities, haemolymph oxyhemocyanin contents and hepatopancreas histology of white shrimp, Litopenaeus vannamei, at various salinities. Aquaculture 274, 80-86.

Lo, S., Russell, J.C., Taylor, A., 1970. Determination of glycogen in small tissue samples. J. App. Physiol. 28, 234-236.

Lopez-Lopez, S., Nolasco, H., Villarreal-Colmenares, H., Civera-Cerecedo, R., 2005. Digestive enzyme response to supplemental ingredients in practical diets for juvenile freshwater crayfish Cherax quadricarinatus. Aquacult. Nutr. 11, 79-85.

Lorentzen, G., Lian, F., Siikavuopio, S.I., 2019. Quality parameters of processed clusters of red king crab (Paralithodes camtschaticus)-effects of live holding at 5 and $10^{\circ} \mathrm{C}$ up to 
92 days without feeding. Food Control 95, 142-149.

Lovrich, G.A., Tapella, F., 2014. Southern King Crabs, King Crabs of the World: Biology and Fisheries Management. CRC Press, Boca Raton, pp. 449-484.

Lovrich, G.A., Vinuesa, J.H., Smith, B.D., 2002. Growth, maturity, and mating of male southern king crab (Lithodes santolla) in the Beagle Channel, Argentina. Crabs in cold water regions: biology, management, and economics Alaska Sea Grant College. Progr. Rep. 2, 147-168.

Mayrand, E., Dutil, J.-D., Guderley, H., 2000. Changes in muscle of postmoult snow crabs Chionoecetes opilio (O. Fabricius) fed different rations. J. Exp. Mar. Biol. Ecol. 243, 95-113.

Moss, S., 1994. Use of nucleic acids as indicators of growth in juvenile white shrimp, Penaeus vannamei. Marine Biol. 120, 359-367.

Ohkawa, H., Ohishi, N., Yagi, K., 1979. Assay for lipid peroxides in animal tissues by thiobarbituric acid reaction. Anal. Biochem. 95, 351-358.

Ong, B.L., Johnston, D., 2006. Influence of feeding on hepatopancreas structure and digestive enzyme activities in Penaeus monodon. J. Shellfish Res. 25, 113-121.

Reznick, A.Z., Packer, L., 1994. Oxidative damage to proteins: spectrophotometric method for carbonyl assay. Methods Enzymol. 233, 357-363.

Rivera-Pérez, C., García-Carreño, F.L., 2011. Effect of fasting on digestive gland lipase transcripts expression in Penaeus vannamei. Mar. Gen. 4, 273-278.

Romero, M.C., Tapella, F., Sotelano, M.P., Ansaldo, M., Lovrich, G.A., 2011. Oxidative stress in the subantarctic false king crab Paralomis granulosa during air exposure and subsequent re-submersion. Aquaculture 319, 205-210.

Sacristán, H.J., Nolasco-Soria, H., López Greco, L.S., 2014. Effect of attractant stimuli, starvation period and food availability on digestive enzymes in the redclaw crayfish Cherax quadricarinatus (Parastacidae). Aquat. Biol. 23, 87-99.

Sacristán, H.J., Fernández-Gimenez, A.V., Chaulet, A., Tadic, F., Marcelo, L., Fenucci, J., López Greco, L.S., 2015. Effect of different diets on digestive enzyme activities, in vitro digestibility, and midgut gland structure in juvenile crayfish, Cherax quadricarinatus. Acta Zool. 97 (407), 418.

Sacristán, H.J., Ansaldo, M., Franco-Tadic, L.M., Fernández-Gimenez, A.V., López Greco, L.S., 2016. Long-term starvation and posterior feeding effects on biochemical and physiological responses of midgut gland of Cherax quadricarinatus juveniles (Parastacidae). PLoS One 11, e0150854.

Sacristán, H.J., Rodríguez, Y.E., De los, Angeles, Pereira, N., López Greco, L.S., Lovrich, G.A., Fernández-Gimenez, A.V., 2017. Energy reserves mobilization: strategies of three decapod species. PLoS One 12, e0184060.
Sainz, J.C., García-Carreño, F., Sierra-Beltrán, A., Hernández-Cortés, P., 2004. Trypsin synthesis and storage as zymogen in the midgut gland of the shrimp Litopenaeus vannamei. J. Crust. Biol. 24, 266-273.

Shao, L., Wang, C., He, J., Wu, X., Cheng, Y., 2014. Meat quality of Chinese mitten crabs fattened with natural and formulated diets. J. Aquat. Food Prod. Technol. 23, 59-72.

Siikavuopio, S.I., James, P., 2015. Effects of temperature on feed intake, growth and oxygen consumption in adult male king crab Paralithodes camtschaticus held in captivity and fed manufactured diets. Aquacult. Res. 46, 602-608.

Siikavuopio, S.I., Martinsen, G., Stenberg, E., Jakobsen, R.A., Carlehög, M., Eilertsen, G., 2011. Kongekrabbe-foredling Og Industriell Bearbeiding. Nofima rapportserie. .

Siikavuopio, S.I., James, P., Olsen, B.R., Evensen, T., Mortensen, A., 2016. Holding wild caught red king crab, Paralithodes camtschaticus: effects of stocking density and feeding on survival and meat content. Aquacult. Res. 47, 870-874.

Siikavuopio, S.I., James, P., Olsen, B.R., Evensen, T., Mortensen, A., Olsen, S.H., 2017. Holding wild Snow crab, Chionoecetes opilio: effects of stocking density and feeding on survival and injury. Aquacult. Res. 48, 1590-1595.

Sousa, L., Petriella, A.M., 2006. Morphology and histology of P. argentinus (Crustacea, Decapoda, Caridea) digestive tract. Biocell 30, 287-294.

Soyer, A., Özalp, B., Dalmış, Ü., Bilgin, V., 2010. Effects of freezing temperature and duration of frozen storage on lipid and protein oxidation in chicken meat. Food Chem. 120, 1025-1030.

Stevens, B.G., 2014. King Crabs of the World: Biology and Fisheries Management. CRC Press.

Tsai, I.-H., Chuano, K.-L., Chuang, J.L., 1986. Chymotrypsins in digestive tracts of crustacean decapods (Shrimps). Comp. Biochem. Physiol. B 85, 235-239.

Versaw, W., Cuppett, S., Winters, D., Williams, L., 1989. An improved colorimetric assay for bacterial lipase in nonfat dry milk. J. Food Sci. 54, 1557-1558.

Vijayavel, K., Gomathi, R., Durgabhavani, K., Balasubramanian, M., 2004. Sublethal effect of naphthalene on lipid peroxidation and antioxidant status in the edible marine crab Scylla serrata. Mar. Pollut. Bull. 48, 429-433.

Yudkovski, Y., Shechter, A., Chalifa-Caspi, V., Auslander, M., Ophir, R., Dauphin-Villemant, C., Waterman, M., Sagi, A., Tom, M., 2007. Hepatopancreatic multi-transcript expression patterns in the crayfish Cherax quadricarinatus during the moult cycle. Insect Mol. Biol. 16, 661-674.

Zuur, A.F., Ieno, E.N., Saveliev, A.A., 2009. Mixed Effects Models and Extensions in Ecology with R. Springer. 